Електронне наукове фахове видання «Адаптивне управління: теорія і практика.

УДК. 374.31

https://doi.org/10.33296/2707-0255-11(21)-18

https://orcid.org/0000-0001-9937-6646

\author{
ШКУРА ГЕННАДІЙ \\ АНАТОЛІЙОВИЧ, \\ директор Українського державного \\ центру позашкільної освіти, \\ аспірант кафедри менеджменту \\ освіти та права ЦІПО ДЗВО \\ «Університет \\ менеджменту освіти» \\ НАПН України
}

\title{
ВИКОРИСТАННЯ ТЕХНОЛОГІЇ МОНІТОРИНГУ УТРУДНЕНЬ У ПРОЄКТНІЙ ДІЯЛЬНОСТІ ЗАКЛАДУ ПОЗАШКІЛЬНОЇ ОСВІТИ
}

Анотація. У статті зазначається актуальність питання щодо використання технології факторно-критеріального моделювання під час проведення моніторингу в системі позашкільної освіти. Акцентовано, що оптимізованим механізмом завдяки використанню комп'ютеризованої кваліметричної факторнокритеріальної моделі утруднень у процесі проєктної діяльності закладу позашкільної освіти $є$ моніторинг утруднень. Обгрунтовано, що проєктменеджеру для ухвалення рішень необхідно відслідковувати стан перебігу проєктної діяльності для розроблення та впровадження проєкту, необхідності корекції або припинення такої діяльності. Описано, дієвий інструмент проведення моніторингу утруднень проєктної діяльності та детально розкрито етапи цієї технології. Розкрито сутність кваліметричної факторно-критеріальної моделі утруднень у процесі проєктної діяльності, яка дасть можливість своєчасно виявити проблеми (за їх наявності), встановити рівень їх проблемності та визначити шляхи подолання. Обгрунтовано доцільність створення такої моделі за факторами, як $є$ напрямами проєктної діяльності: загальне керівництво; цілепокладання; планування; командоутворення; тайм-менеджмент; ресурсний менеджмент; управління ризиками; зовнішні впливи. Висвітлено особливості моніторингу утруднень у процесі проєктної діяльності в закладі позашкільної освіти, описано відповідну кваліметричну факторно-критеріальну модель як інструмент такого моніторингу та основні принципи їі комп’ютеризації. Описано процедуру створення моделі шляхом залучення експертної групи, до складу якої увійшли фахівці у галузі менеджменту освіти - кожен із зазначених факторів був розкладений на критерії, які його розкривають в достатній мірі. У статті наводяться протоколи, що заповнюються експертною групою та графічний покритеріальний аналіз динаміки утруднень у процесі проєктної діяльності. Зазначаються перспективи подальших досліджень. Стаття $\epsilon$ корисною для

\footnotetext{
(c) Українська інженерно-педагогічна академія

(c) ГО «Школа адаптивного управління соціально-педагогічними системами»

(c) Шкура Г.
} 
Електронне наукове фахове видання «Адаптивне управління: теорія і практика.

керівників закладів позашкільної освіти, працівників органів управління в галузі освіти та закладів системи післядипломної педагогічної освіти.

Ключові слова: управління, кваліметрія, заклад позашкільної освіти, факторно-критеріальна модель, утруднення, проєктна діяльність, розвиток, комп’ютеризація.

Вступ. Процеси управління проєктною діяльністю в закладі позашкільної освіти в педагогічній літературі на сьогодні висвітлено не в повній мірі. Зокрема, механізму моніторингу такої діяльності приділено надто мало уваги. Зазначене питання може бути значно оптимізованим завдяки використанню комп'ютеризованої кваліметричної факторно-критеріальної моделі утруднень у процесі проєктної діяльності.

Аналіз останніх публікацій. Теоретичні засади проєктної діяльності висвітлюються у працях $\quad$ В. Гузєєва, О. Коберника, Н. Матяш, О. Пєхоти, Є. Полат, В. Радіонова, В. Слободченкова, С. Сисоєвої, І. Шендрик та ін.

Зміст і значення проектної діяльності розглянуто у публікаціях А. Вдовиченко, А. Касперського, О. Коберника, В. Сидоренка, А. Терещука, Л. Хоменко та інших науковців.

Різні аспекти педагогічної кваліметрії досить глибоко висвітлені у дослідженнях доктора педагогічних наук Галини Єльникової та членів Школи адаптивного управління (Т. Борова, О. Касьянова, В. Лунячек, Г. Полякова, В. Приходько, 3. Рябова, Г. Сухович, С. Фесік та ін.) $[1 ; 2 ; 5]$.

Формулювання цілей статті (постановка завдання): опис кваліметричної факторно-критеріальної моделі утруднень у процесі проєктної діяльності в закладі позашкільної освіти та описати процес використання їі комп'ютерного варіанту.

Виклад основного матеріалу. Одним 3 важливих етапів проєктної діяльності в закладі позашкільної освіти (далі - ЗПО) є іï моніторинг. Проєктменеджеру стан справ важливо відслідковувати для прийняття рішень щодо перебігу розроблення та впровадження проєкту, необхідності корекції або

\footnotetext{
(c) Українська інженерно-педагогічна академія

(C) ГО «Школа адаптивного управління соціально-педагогічними системами»

(C) Шкура Г.
} 
Електронне наукове фахове видання «Адаптивне управління: теорія і практика.

Серія «Педагогіка»

Випуск 11(21), 2021

припинення такої діяльності [3;4]. Зручним інструментом для такого моніторингу може стати кваліметрична факторно-критеріальна модель утруднень у процесі проєктної діяльності, яка дасть можливість своєчасно виявити проблеми (за їх наявності) та встановити рівень їх проблемності.

Для створення такої моделі за фактори ми взяли основні напрями проєктної діяльності, а саме:

1. Загальне керівництво.

2. Цілепокладання.

3. Планування.

4. Командоутворення.

5. Тайм-менеджмент.

6. Ресурсний менеджмент.

7. Управління ризиками.

8. Зовнішні впливи.

Експертною групо, до складу якої увійшли досвідчені ЗПО та наукові працівники наукових установ системи освіти- фахівці у галузі менеджменту освіти - кожен із зазначених факторів був розкладений на критерії, які його розкривають в достатній мірі.

Зокрема, фактор «Загальне керівництво» висвітлюють такі чинники:

- надмірне втручання адміністрації;

- відсутність підтримки адміністрацією;

- відсутність дієвого контролю;

- відсутність або нераціональність корекції;

- відсутність рефлексії.

Фактор «Цілепокладання» достатньо повно розкривають наступні показники:

- нераціональне формулювання мети проєкту;

- нераціональне формулювання завдань;

- постановка нездійсненого завдання;

(C) Українська інженерно-педагогічна академія

(C) ГО «Школа адаптивного управління соціально-педагогічними системами»

(C) Шкура Г. 
Електронне наукове фахове видання «Адаптивне управління: теорія і практика.

- перевантаження запланованими діями;

- переоцінка результату діяльності.

До фактору «Планування» увійшли відповідні критерії:

- помилкове визначення інноваційності проєкту;

- помилкове визначення унікальності проєкту;

- неврахування особливостей діяльності ЗПО;

- невідпрацьованість критеріїв оцінювання результатів (проміжних та/або кінцевих).

Один із найважливіших факторів - «Командоутворення» - складається 3 найбільшої кількості критеріїв, а саме:

- невдалий вибір лідера проєкту;

- замикання надто багатьох питань на лідерові проєкту;

- слабка комунікація членів команди;

- недостатній фаховий рівень членів команди;

- недостатня мотивація членів команди;

- протидія проєкту в колективі;

- невиправдана заміна виконавців;

- недостатньо повноважень у членів команди;

- нераціональний розподіл обов'язків між членами команди.

Критерії, які стосуються часових показників проєктної діяльності, склали «команду» фактора «Тайм-менеджмент»:

- невдалий графік розроблення проєкту;

- невдалий графік впровадження проєкту;

- втрата актуальності проєкту;

- «розповзання» масштабу проєкту.

Шостий фактор - «Ресурсний менеджмент» - у достатній мірі розкриваються трьома критеріями:

- помилковий розрахунок ресурсів проєкту;

- помилки у розрахунку бюджету проєкту; 
Електронне наукове фахове видання «Адаптивне управління: теорія і практика.

- невиправдані витрати.

Показники щодо ризиків проєктної діяльності в ЗПО склали систему критеріїв фактора «Управління ризиками»:

- недооцінка ризиків;

- недостатність досвіду щодо подолання ризиків;

- невдале управління ризиками.

Останній фактор «Зовнішні впливи» аналізується за допомогою таких критеріїв:

- неврахування соціальної нестабільності;

- завеликий вплив соціальної нестабільності;

- втрата зацікавленості стейкхолдерів.

Але самі по собі ні фактори, ні критерії не без відповідних числових значень не дадуть необхідного матеріалу для аналізу утруднень у процесі проєктної діяльності. Тому вони «були забезпечені» відповідними числовими показниками - вагомостями, які визначають їхнє конкретне значення.

Далі експертною групою були встановлені критерії оцінювання в межах моделі - які експертні бали у якому випадку виставляються експертами у процесі оцінювання. Ми відмовилися від наддрібних експертних балів, оскільки достатньо чітку межу між ними надто складно встановити, та й виставляти такі бали складно і нераціонально. Тому члени експертної групи зупинилися на таких критеріях оцінювання:

1 бал - утруднення відчуваються постійно;

0,75 бала - утруднення відчуваються часто;

0,5 бала - утруднення відчуваються час від часу;

0,25 - утруднення відчуваються рідко;

0 балів - утруднення практично не відчуваються.

Експерти також визначили межі рівнів утруднень на підставі суми отриманих експертних балів:

1 - 0,87 бала - критичний рівень;

\footnotetext{
(c) Українська інженерно-педагогічна академія

(C) ГО «Школа адаптивного управління соціально-педагогічними системами»

(C) Шкура Г.
} 
0,86 - 0,7 бала - високий рівень;

$0,69-0,5$ бала - середній рівень:

0,49 - 0,2 бала - допустимий рівень;

0,19 - 0 балів - низький рівень.

Після того, як були визначені основні показники, було створено базову модель кваліметричної факторно-критеріальної моделі утруднень у процесі проєктної діяльності в закладі позашкільної освіти (додаток 1).

Наступним завданням стало розроблення комп'ютеризованого варіанту зазначеної моделі 3 урахуванням можливості здійснення відповідного моніторингу. На нашу думку, оптимальним варіантом вирішення цього питання $\epsilon$ створення моделі в табличному редакторі Excel, оскільки на кожному комп'ютері встановлено пакет програм «Office, який обов'язково містить зазначений табличний редактор, для користування яким немає потреби встановлювати додаткові програми або драйвери.

Отже, вкладками (сторінками) такої моделі були обрані наступні: «Базова», «Бланк», «Дані», «Зведена», «Діаграма».

Вкладка «Базова» містить базову модель кваліметричної факторнокритеріальної моделі утруднень у процесі проєктної діяльності в ЗПО, де зазначено фактори, критерії, їх вагомості та механізм підрахунку сумарного (кінцевого) результату.

У вкладці «Бланк» розміщено бланк протоколу експертизи рівня утруднень у процесі проєктної діяльності в ЗПО. Під заголовком бланка зазначається назва ЗПО, яка в подальшому відтворюється на інших вкладках автоматично - на відповідну комірку із зазначенням назви ЗПО робиться посилання (табл.1).

(C) Українська інженерно-педагогічна академія

(C) ГО «Школа адаптивного управління соціально-педагогічними системами»

(C) Шкура Г. 
Електронне наукове фахове видання «Адаптивне управління: теорія і практика.

\section{ПРОТОКОЛ}

визначення утруднень у процесі проєктної діяльності

Украӥнський державний центр позашкільної освіти (Фрагмент вкладки «Бланк» (верхня частина протоколу))

\begin{tabular}{|c|l|c|}
\hline \multirow{2}{*}{$№$} & \multicolumn{1}{|c|}{ Критерій } & $\begin{array}{c}\text { Експерт- } \\
\text { ний бал }\end{array}$ \\
\hline 1 & Надмірне втручання адміністрації & \\
\hline 2 & Відсутність підтримки адміністрацією & \\
\hline 3 & Відсутність дієвого контролю & \\
\hline 4 & Відсутність або нераціональність корекції & \\
\hline 5 & Відсутність рефлексії & \\
\hline
\end{tabular}

Під таблицею протоколу зазначаються критерії оцінювання, дата експертизи, ініціали та прізвище експерта. Ця вкладка відформатована для зручного друку бланку протоколу на одному аркуші паперу формату A4: на лицьовій стороні аркуша друкується таблиця протоколу, а на звороті - критерії оцінювання та місце для підпису протоколу експертом . На звороті бланка друку. Роздруковані бланки протоколів роздаються експертам для заповнення (табл.2).

\section{Фрагмент вкладки «Бланк» (нижня частина протоколу)}

$\left.\begin{array}{|l|l|l|}\hline 34 & \text { Неврахування соціальної нестабільності } \\ \hline 35 & \text { Завеликий вплив соціальної нестабільності } \\ \hline 36 & \text { Втрата зацікавленості стейкхолдерів }\end{array}\right]$

\section{Критерії оцінювання:}

1 бал - утруднення відчуваються постійно;

0,75 бала - утруднення відчуваються часто;

0,5 бала - утруднення відчуваються час від часу;

0,25 бала - утруднення відчуваються часто;

(C) Українська інженерно-педагогічна академія

(C) ГО «Школа адаптивного управління соціально-педагогічними системами»

(C) Шкура Г. 
0 балів - утруднення практично не відчуваються.

Експертні бали 3 протоколів заносяться до відкритої таблиці вкладки «Дані».

Вкладка «Дані» містить дві таблиці. У першу таблицю, відкриту для введення будь-яких числових показників, вносяться дані з протоколів експертизи. Перелік критеріїв моделі виводиться автоматично шляхом посилання на відповідні комірки вкладки «Бланк». Ці показники, а також назва таблиці та назва ЗПО захищені від несанкціонованого втручання.

У головці таблиці, крім назви, зазначаються терміни експертизи - ці комірки відкриті для введення даних і не є захищеними. У першу з них додано примітку «Вказати термін експертизи», яка з'являється після наведення курсора на цю комірку (табл. 3).

Таблиця розрахована на проведення п’ятьох експертиз, що дає можливість у повній мірі здійснювати моніторинг утруднень. Доцільними, на нашу думку, $є$ такі етапи проєктної діяльності:

1) через півтора-два тижні від початку розроблення проєкту;

2) орієнтовно посередині розроблення проєкту (відповідно до плану);

3) після розроблення проєкту;

4) через півтора-два тижні від початку впровадження проєкту в діяльність ЗПО;

5) після впровадження проєкту в діяльність ЗПО та його презентації. 
Електронне наукове фахове видання «Адаптивне управління: теорія і практика.

\section{Дані}

\section{експертизи утруднень у процесі просктної діяльності}

Украӥнський державний центр позашкільної освіти (Фрагмент вкладки «Дані» (верхня частина відкритої таблиці))

\begin{tabular}{|c|l|c|c|c|c|}
\hline № & \multicolumn{1}{|c|}{ Фактори. Критерії } & $\mathbf{0 1 . 1 0 . 2 0 2 0}$ & $\mathbf{0 1 . 1 2 . 2 0 2 0}$ & $\mathbf{1 0 . 0 1 . 2 0 2 1}$ & $\mathbf{0 1 . 0 2 . 2 0 2 1}$ \\
\hline 1 & $\begin{array}{l}\text { Надмірне втручання } \\
\text { адміністрації }\end{array}$ & 1 & 0,75 & 0 & 0 \\
\hline 2 & $\begin{array}{l}\text { Відсутність підтримки } \\
\text { адміністрацією }\end{array}$ & 0,25 & 0,25 & 0 & 0 \\
\hdashline 3 & Відсутність дісвого контролю & 0,25 & 0,25 & 0 & 0,25 \\
\hline 4 & $\begin{array}{l}\text { Відсутність або } \\
\text { нераціональність корекції }\end{array}$ & 0,5 & 0,25 & 0,25 & 0 \\
\hline 5 & Відсутність рефлексії & 0,25 & 0 & 0 & 0 \\
\hline
\end{tabular}

Зазначені «точки моніторингу» дають можливість робити висновки на різних і найбільш важливих та найбільш показових етапах проєктної діяльності в ЗПО.

Друга таблиця вкладки «Дані» є прихованою, оскільки в ній здійснюються суто технічні дії - обрахунки показників 3 першої таблиці 3 урахуванням вагомостей критеріїв і факторів описуваної моделі (табл. 4).

Таблиця 4.

\section{Фрагмент вкладки «Дані» (верхня частина прихованої таблиці)}

\begin{tabular}{|c|c|c|c|c|c|c|}
\hline & 01.10 .2020 & 01.10 .2020 & 01.12 .2020 & 10.01 .2021 & 01.02 .2021 \\
\hline & & & Доп. & Доп. & Низьк. & Низьк. \\
\hline & & Допустимий & Допустимий & Допустимий & Низький & Низький \\
\hline & & $\underline{0,32}$ & $\underline{0,32}$ & $\underline{0,22}$ & $\underline{0,18}$ & $\underline{0,14}$ \\
\hline 0,17 & $\begin{array}{c}\text { Загальне } \\
\text { керівництво } \\
\end{array}$ & $\underline{0,08}$ & 0,08 & 0,07 & 0,05 & 0,04 \\
\hline
\end{tabular}


Електронне наукове фахове видання «Адаптивне управління: теорія і практика.

\begin{tabular}{|c|c|c|c|c|c|c|}
\hline 0,15 & $\begin{array}{l}\text { надмірне } \\
\text { втручання } \\
\text { адміністрації }\end{array}$ & $\underline{0,15}$ & 0,15 & 0,11 & 0,08 & 0,04 \\
\hline 0,27 & $\begin{array}{l}\text { відсутність } \\
\text { підтримки } \\
\text { адміністрацією }\end{array}$ & $\underline{0,07}$ & 0,07 & 0,07 & 0,00 & 0,00 \\
\hline 0,24 & $\begin{array}{l}\text { відсутність } \\
\text { дієвого } \\
\text { контролю }\end{array}$ & $\underline{0,12}$ & 0,12 & 0,12 & 0,12 & 0,06 \\
\hline 0,17 & $\begin{array}{l}\text { відсутність або } \\
\text { нераціональність } \\
\text { корекції }\end{array}$ & $\underline{0,09}$ & 0,09 & 0,09 & 0,09 & 0,09 \\
\hline 0,17 & $\begin{array}{l}\text { відсутність } \\
\text { рефлексії }\end{array}$ & $\underline{0,04}$ & 0,04 & 0,04 & 0,04 & 0,04 \\
\hline
\end{tabular}

За допомогою відповідних формул не лише обраховуються експертні бали, а й визначаються рівні утруднень з урахуванням визначених експертною групою меж. Наприклад, вагомість першого критерія «Надмірне втручання адміністрації» обраховується за такою формулою:

$$
=\text { ЕСЛИ(Е6=""';"';Е6*\$В57/4), }
$$

де:

E6 - посилання на відносну адресу комірки, в якій розміщено експертний бал за цей критерій (комірка відкритої таблиці);

В57 - посилання на абсолютну адресу комірки, в якій зазначено вагомість цього критерія (комірка прихованої таблиці, яка виконує технічні функції).

Блок формули «ЕСЛИ(Е6=""';"";» означає, що у комірці, в якій розміщено формулу, не буде відтворено жодного знаку або символу, якщо в комірці Е6 не буде розміщено жодного знаку або символу. Тобто, за відсутності будь-яких даних у комірці Е6 у комірці формули не буде відтворено знак помилкової формули «\#ЗНАЧ!».

Також в описуваній таблиці виводяться скорочені позначення рівнів для відтворення їх у таблиці вкладки «Зведена 2». Наприклад, високий рівень утруднень має скорочення «Висок.», середній - «Середн.» і т.д.

\footnotetext{
(C) Українська інженерно-педагогічна академія

(C) ГО «Школа адаптивного управління соціально-педагогічними системами»

(C) Шкура Г.
} 
Електронне наукове фахове видання «Адаптивне управління: теорія і практика.

Вкладка «Зведений» має три основних складових. Спочатку розміщені основні дані за підсумками експертизи (рис. 1).

\section{РЕЗУЛЬТАТИ}

визначення утруднень у процесі проєктної діяльності

Заклад: Український державний иенттр позашкільної освіти

Термін експертизи:

Експертний бал:

Рівень утруднень:

\begin{tabular}{|l|l|}
\hline 01.10 .2020 & $\nabla$ \\
\hline & $\mathbf{0 , 3 2}$
\end{tabular}

Допустимий

Рис. 1. Фрагмент вкладки «зведений» (основні дані)

Далі розташована таблиця, у якій пофакторно зазначено утруднення у відсотках (табл.5).

Таблиця 5

Таблиця вкладки «зведений»

\begin{tabular}{|c|l|c|}
\hline № & \multicolumn{1}{|c|}{ Фактори } & Відсоток утруднень \\
\hline $\mathbf{1}$ & Загальне керівництво & $\mathbf{4 7 \%}$ \\
\hline 2 & Цілепокладання & $\mathbf{5 8 \%}$ \\
\hline $\mathbf{3}$ & Планування & $\mathbf{4 2 \%}$ \\
\hline $\mathbf{4}$ & Командоутворення & $\mathbf{2 8 \%}$ \\
\hline $\mathbf{5}$ & Тайм-менеджмент & $\mathbf{1 0 \%}$ \\
\hline $\mathbf{6}$ & Ресурсний менеджмент & $\mathbf{0 \%}$ \\
\hline $\mathbf{7}$ & Управління ризиками & $\mathbf{8 \%}$ \\
\hline $\mathbf{8}$ & Зовнішні впливи & $\mathbf{5 \%}$ \\
\hline
\end{tabular}

Після таблиці створено діаграму утруднень у процесі проєктної діяльності, яка візуально унаочнює подану вище таблицю (рис.2). 
Електронне наукове фахове видання «Адаптивне управління: теорія і практика. Серія «Педагогіка»

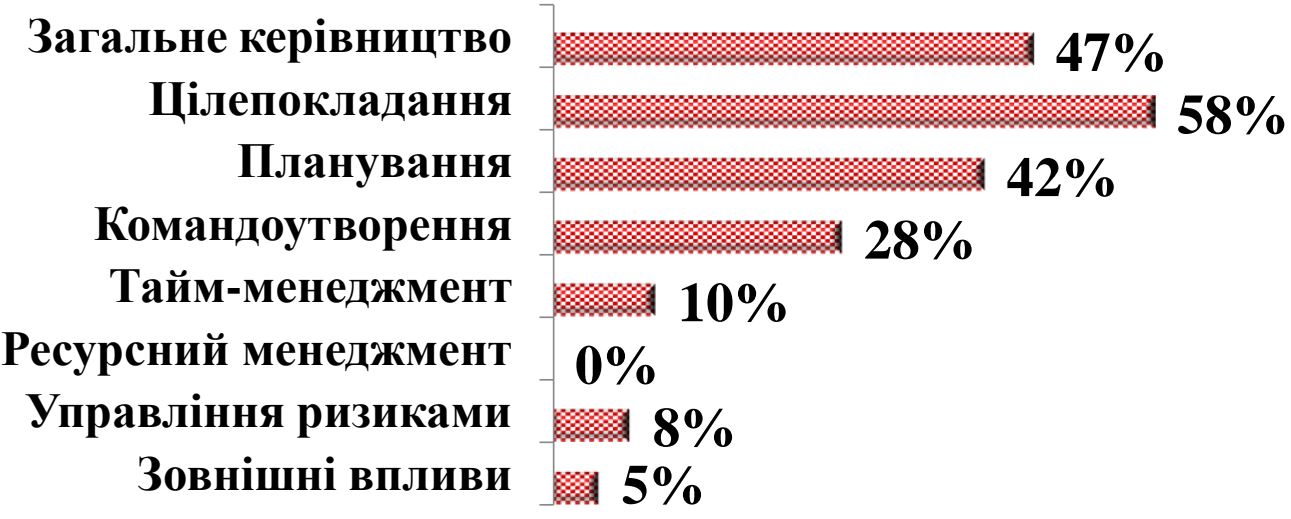

Рис. 2. Діаграма вкладки «Зведений»

У вкладці «Зведений 2» крім заголовка сторінки та назви ЗПО розміщено таблицю, в якій пофакторно порівнюються показники утруднень (у відсотках) у різні терміни експертизи, а також графічний профіль утруднень, що візуально унаочнює показники таблиці (табл. 6).

Таблиця 6

Таблиця вкладки «Зведений 2»

\begin{tabular}{|c|l|c|c|c|c|c|}
\hline \multirow{2}{*}{ № } & \multicolumn{2}{|c|}{ Фактори } & \multicolumn{5}{|c|}{ Термін експертизи } \\
\cline { 3 - 7 } & \multicolumn{2}{|c|}{01.10 .2020} & 01.12 .2020 & 10.01 .2021 & 01.02 .2021 & \\
\hline $\mathbf{1}$ & Загальне керівництво & 0,08 & 0,07 & 0,05 & 0,04 & \\
\hline $\mathbf{2}$ & Цілепокладання & 0,09 & 0,06 & 0,03 & 0,01 & \\
\hline $\mathbf{3}$ & Планування & 0,06 & 0,05 & 0,03 & 0,03 & \\
\hline $\mathbf{4}$ & Командоутворення & 0,07 & 0,03 & 0,04 & 0,03 & \\
\hline $\mathbf{5}$ & Тайм-менеджмент & 0,01 & 0,00 & 0,01 & 0,02 & \\
\hline $\mathbf{6}$ & $\begin{array}{l}\text { Ресурсний } \\
\text { менеджмент }\end{array}$ & 0,00 & 0,00 & 0,01 & 0,01 & \\
\hline $\mathbf{7}$ & Управління ризиками & 0,00 & 0,00 & 0,00 & 0,00 & \\
\hline $\mathbf{8}$ & Зовнішні впливи & 0,00 & 0,00 & 0,00 & 0,00 & \\
\hline \multicolumn{2}{|l|}{ Експертний бал } & $\mathbf{0 , 3 2}$ & $\mathbf{0 , 2 1}$ & $\mathbf{0 , 1 8}$ & $\mathbf{0 , 1 4}$ & \\
\hline \multicolumn{2}{|c|}{ Рівень утруднень } & Доп. & Доп. & Низьк. & Низьк. & \\
\hline
\end{tabular}

Дані цієї таблиці виводяться за допомогою формул-посилань на відповідні комірки прихованої таблиці вкладки «Дані». Наприклад, дата першої експертизи виводиться за допомогою формули-посилання:

$$
\text { =ЕСЛИ(Дані!Е5="'";"';Дані!Е5), }
$$


Електронне наукове фахове видання «Адаптивне управління: теорія і практика. Серія «Педагогіка»

де Дані!E5 - відносна адреса комірки Е5 вкладки «Дані», де розміщено перший термін експертизи.

Принцип дії частини формули «Дані!E5="'";"';» описано вище.

Вкладка «Зведений 2» після таблиці розміщує пелюсткову діаграму «Графічний профіль утруднень у процесі проєктної діяльності , яка пофакторно унаочнює динаміку змін щодо зазначених утруднень (рис. 3).

Графічний покритеріальний аналіз динаміки утруднень у процесі проєктної діяльності містить вкладка «Діаграма». Усі іiі дані виведено теж за допомогою прихованих формул-посилань на відповідні комірки вкладки «Дані». Поле цієї діаграми розділено кольоровими лініями відповідно до рівнів утруднень.

\section{Графічний профіль}

утруднень у процесі просктної діяльності



\section{Рис. 3. Пелюсткова діаграма вкладки «Зведений 2»}

Це полегшує сприйняття даних діаграми та співвідношення їх 3 відповідними рівнями утруднень.

Висновки. Перспективи подальших досліджень. Таким чином, використання комп’ютеризованої кваліметричної факторно-критеріальної моделі утруднень у процесі проєктної діяльності в ЗПО сприятиме своєчасному

\footnotetext{
(C) Українська інженерно-педагогічна академія

(C) ГО «Школа адаптивного управління соціально-педагогічними системами»

(C) Шкура Г.
} 
Електронне наукове фахове видання «Адаптивне управління: теорія і практика.

виявленню самих утруднень і рівня їх проблемності з метою оптимального їх подолання.

Подальшими дослідженнями у зазначеній площині буде підготовка системи рекомендацій відповідно до результатів описаної експертизи.

\section{Використані джерела}

1. Адаптивне управління: міжгалузеві зв'язки, науково-прикладний аспект: кол. монографія / Г. В. Сльникова, Т. А. Борова, 3. В. Рябова та ін.; за заг. і наук. ред. Г. В. Сльникової. Харків: Мачулін, 2017. 440 с.

2. Сльникова Г.В. Моніторинг як ефективний засіб оцінювання якості загальної середньої освіти в навчальному закладі [електронний ресурс] / $\begin{array}{llll}\text { Г. В. Сльникова, } & \text { 3. В. Рябова. - Режим доступу }\end{array}$ http://dspace.nbuv.gov.ua/handle/123456789/107549

3. Сльникова Галина. Адаптивні технології в освіті [електронний ресурс] / Галина Єльникова. - Електронне наукове фахове видання «Адаптивне управління: теорія і практика» Серія «Педагогіка» Випуск 3(5), 2017. - Режим доступу: http://am.eor.in.ua/images/adapt/Vol.3ped5/17ped3_5yelnikova_r.pdf

4. Організаційно-методичне забезпечення моніторингових досліджень якості загальної середньої освіти : монографія / за ред. О. І. Ляшенко - К. : Пед. думка, 2011. - 160 с.

5. Рябова, 3. (2020). Моніторинг професійної компетентності майбутніх фахівців. Адаптивне управління: теорія і практика. Серія Педагогіка, 10(19). Retrieved is https://amtp.org.ua/index.php/journal/article/view/390

\section{References}

1. Adaptyvne upravlinnia: mizhhaluzevi zviazky, naukovo-prykladnyi aspekt: kol. monohrafiia / H. V. Yelnykova, T. A. Borova, Z. V. Riabova ta in.; za zah. i nauk. red. H. V. Yelnykovoi. Kharkiv: Machulin, 2017. $440 \mathrm{s.}$

2. Ielnykova H. V. Monitorynh yak efektyvnyi zasib otsiniuvannia yakosti zahalnoi serednoi osvity v navchalnomu zakladi [elektronnyi resurs] / H. V. Yelnykova, Z. V. Riabova. - $\quad$ Rezhym dostupu http://dspace.nbuv.gov.ua/handle/123456789/107549

3. Ielnykova Halyna. Adaptyvni tekhnolohii v osviti [elektronnyi resurs] / Halyna Yelnykova. - Elektronne naukove fakhove vydannia «Adaptyvne upravlinnia: teoriia i praktyka» Seriia «Pedahohika» Vypusk 3(5), 2017. - Rezhym dostupu: http://am.eor.in.ua/images/adapt/Vol.3ped5/17ped3_5yelnikova_r.pdf

4. Orhanizatsiino-metodychne zabezpechennia monitorynhovykh doslidzhen yakosti zahalnoi serednoi osvity : monohrafiia / za red. O. I. Liashenko - K. : Ped. dumka, 2011. - $160 \mathrm{~s}$.

5. Riabova, Z. (2020). Monitorynh profesiinoi kompetentnosti maibutnikh

\footnotetext{
(c) Українська інженерно-педагогічна академія

(c) ГО «Школа адаптивного управління соціально-педагогічними системами»

(C) Шкура Г.
} 
Електронне наукове фахове видання «Адаптивне управління: теорія і практика.

Серія «Педагогіка»

Випуск 11(21), 2021

fakhivtsiv. Adaptyvne upravlinnia: teoriia i praktyka. Seriia Pedahohika, 10(19). Retrieved iz https://amtp.org.ua/index.php/journal/article/view/390

\author{
ШКУРА ГЕННАДИЙ \\ АНАТОЛИЕВИЧ, \\ директор Украинского \\ государственного \\ центра внешкольного образования, \\ аспирант кафедры менеджмента \\ образования и права ЦИПО ДВВО \\ «Университет \\ менеджмента образования» \\ НАПН Украины
}

\title{
ИСПОЛЬЗОВАНИЕ ТЕХНОЛОГИИ МОНИТОРИНГА ЗАТРУДНЕНИЙ В ПРОЕКТНОЙ ДЕЯТЕЛЬНОСТИ ЗАВЕДЕНИЯ ВНЕШКОЛЬНОГО ОБРАЗОВАНИЯ
}

Аннотация. В статье отмечается актуальность вопроса использования технологии факторно-критериального моделирования во время проведения мониторинга в системе внешкольного образования. Акцентировано, что оптимизиованным механизмом благодаря использованию компьютеризированной квалиметрической факторно-критериальной модели затруднений в процессе проектной деятельности заведения внешкольного образования является мониторинг затруднений. Обосновано, что проектменеджеру для принятия решений необходимо отслеживать состояние проектной деятельности для разработки и внедрения проекта, необходимости коррекции или прекращения такой деятельности. Описан действенный инструмент проведения мониторинга затруднений проектной деятельности и детально раскрыты этапы этой технологии. Раскрыта сущность квалиметрической факторно-критериальной модели затруднений в процессе проектной деятельности, которая позволит своевременно выявить проблемы (при их наличии), установить уровень их проблемности и определить пути преодоления. Обоснована целесообразность создания такой модели по факторам, как направления проектной деятельности: общее руководство; целеполагание; планирование; командообразование; таймменеджмент; ресурсный менеджмент; управление рисками; внешние воздействия. Отражены особенности мониторинга затруднений в процессе проектной деятельности в заведении внешкольного образования, описана соответствующая квалиметрическая факторно-критериальная модель как инструмент такого мониторинга и основные принципы его компьютеризации. Описана процедура создания модели путем привлечения экспертной группы, в состав которой вошли специалисты в области менеджмента образования - каждый из указанных факторов был разложен на критерии, раскрывающие его в достаточной степени. В статье приводятся протоколы, заполняемые экспертной группой и графический

\footnotetext{
(C) Українська інженерно-педагогічна академія

(c) ГО «Школа адаптивного управління соціально-педагогічними системами»

(c) Шкура Г.
} 
Електронне наукове фахове видання «Адаптивне управління: теорія і практика.

критериальный анализ динамики затруднений в процессе проектной

деятельности. Указываются перспективы дальнейших исследований. Статья полезна для руководителей учреждений внешкольного образования, работников органов управления в области образования и учреждений системы последипломного педагогического образования.

Ключевые слова: управление, квалиметрия, учреждение внешкольного образования, факторно-критериальная модель, затруднения, проектная деятельность, развитие, компьютеризация.

\author{
SHKURA HENNADIY, \\ Director of the Ukrainian State \\ center of extracurricular education, \\ graduate student of the Department \\ of Management \\ education and law TsIPO DZVO \\ "University \\ Education Management » \\ NAPS of Ukraine
}

\title{
USE OF EQUIPMENT MONITORING TECHNOLOGY IN THE DESIGN ACTIVITIES OF THE OUT-SCHOOL EDUCATION INSTITUTION
}

Annotation. The article notes the relevance of the issue of using the technology of factor-criterion modeling during monitoring in the out-of-school education system. It is emphasized that an optimized mechanism due to the use of a computerized qualimetric factor-criterion model of difficulties in the process of project activities of an institution of out-of-school education is the monitoring of difficulties. It is substantiated that the project manager for making decisions needs to monitor the state of project activities for the development and implementation of the project, the need for correction or termination of such activities. An effective tool for monitoring the difficulties of project activities is described and the stages of this technology are disclosed in detail. The essence of the qualimetric factor-criterion model of difficulties in the process of project activities is revealed, which will allow timely identification of problems (if any), establish the level of their problematicity and determine ways to overcome them. The expediency of creating such a model has been substantiated by factors such as directions of project activities: general management; goal setting; planning; team building; time management; resource management; Management of risks; external influences. The features of monitoring difficulties in the process of project activities in the institution of out-of-school education are reflected, the corresponding qualimetric factor-criterion model is described as a tool for such monitoring and the basic principles of its computerization. The procedure for creating a model by involving an expert group, which included specialists in the field of education management, is described - each of these factors was decomposed into criteria that

\footnotetext{
(c) Українська інженерно-педагогічна академія

(c) ГО «Школа адаптивного управління соціально-педагогічними системами»

(C) Шкура Г.
} 
Електронне наукове фахове видання «Адаптивне управління: теорія і практика.

sufficiently reveal it. The article presents the protocols filled in by the expert group and a graphical criterial analysis of the dynamics of difficulties in the process of project activities. Prospects for further research are indicated. The article is useful for heads of out-of-school education institutions, employees of educational authorities and institutions of the system of postgraduate pedagogical education.

Key words: management, qualimetry, out-of-school education institution, factorcriterion model, difficulties, project activities, development, computerization. 
Факторно-критеріальна модель визначення утруднень у процесі просктної діяльності

\begin{tabular}{|c|c|c|c|c|}
\hline Фактори (Ф) & $\begin{array}{l}\text { Ваго- } \\
\text { мість } \\
\text { (m) }\end{array}$ & Критерії (K) & $\begin{array}{l}\text { Ваго- } \\
\text { мiсть } \\
(\mathbf{v})\end{array}$ & $\begin{array}{c}\text { Коеф. } \\
\text { відпо- } \\
\text { відості } \\
\text { (k) }\end{array}$ \\
\hline \multirow{2}{*}{$\begin{array}{l}\text { 1. Загальне } \\
\text { керівництво }\end{array}$} & \multirow{5}{*}{$\begin{array}{l}\mathrm{m} 1= \\
0,17\end{array}$} & 1. Надмірне втручання адміністрації & $\mathrm{v} 1=0,15$ & $\mathrm{~K} 1=$ \\
\hline & & 2. Відсутність підтримки адміністрацією & $\mathrm{v} 2=0,27$ & $\mathrm{~K} 2=$ \\
\hline \multirow{3}{*}{$\begin{array}{l}\Phi 1=\mathrm{m} 1(\mathrm{v} 1 * \mathrm{k} 1+ \\
+\mathrm{v} 2 * \mathrm{k} 2+\mathrm{v} 3 * \mathrm{k} 3+ \\
+\mathrm{v} 4 * \mathrm{k} 4+\mathrm{v} 5 * \mathrm{k} 5)\end{array}$} & & 3. Відсутність дієвого контролю & $\mathrm{v} 3=0,24$ & $\mathrm{~K} 3=$ \\
\hline & & 4. Відсутність або нераціональність корекції & $\mathrm{v} 4=0,17$ & $\mathrm{~K} 4=$ \\
\hline & & 5. Відсутність рефлексії & $\mathrm{v} 5=0,17$ & $\mathrm{~K} 5=$ \\
\hline 2. Цілепокладання & \multirow{5}{*}{$\begin{array}{l}\mathrm{m} 2= \\
0,15\end{array}$} & 6. Нераціональне формулювання мети проєкту & $\mathrm{v} 6=0,23$ & $\mathrm{~K} 6=$ \\
\hline \multirow{4}{*}{$\begin{array}{l}\Phi 2=\mathrm{m} 2(\mathrm{v} 6 * \mathrm{k} 6+ \\
+\mathrm{v} 7 * \mathrm{k} 7+\mathrm{v} 8 * \mathrm{k} 8+ \\
+\mathrm{v} 9 * \mathrm{k} 9+\mathrm{v} 10 * \mathrm{k} 10)\end{array}$} & & 7. Нераціональне формулювання завдань & $\mathrm{v} 7=0,22$ & $\mathrm{~K} 7=$ \\
\hline & & 8. Постановка нездійсненого завдання & $\mathrm{v} 8=0,22$ & $\mathrm{~K} 8=$ \\
\hline & & 9. Перевантаження запланованими діями & $\mathrm{v} 9=0,17$ & $\mathrm{~K} 9=$ \\
\hline & & 10. Переоцінка результату діяльності & $\mathrm{v} 10=0,16$ & $\mathrm{~K} 10=$ \\
\hline 3. Планування & \multirow{3}{*}{$\begin{array}{l}\mathrm{m} 3= \\
0,15\end{array}$} & 11. Помилкове визначення інноваційності проєкту & $\mathrm{v} 11=0,18$ & $\mathrm{~K} 11=$ \\
\hline \multirow{2}{*}{$\begin{array}{l}\Phi 3=\mathrm{m} 3(\mathrm{v} 11 * \mathrm{k} 11+ \\
+\mathrm{v} 12 * \mathrm{k} 12+\mathrm{v} 13 * \mathrm{k} 13+\end{array}$} & & 12. Помилкове визначення унікальності проєкту & $\mathrm{v} 12=0,17$ & $\mathrm{~K} 12=$ \\
\hline & & 13. Неврахування особливостей діяльності ЗПО & $\mathrm{v} 13=0,4$ & $\mathrm{~K} 13=$ \\
\hline
\end{tabular}

\footnotetext{
(C) Українська інженерно-педагогічна академія

(C) ГО «Школа адаптивного управління соціально-педагогічними системами»

(C) Шкура Г.
} 
Електронне наукове фахове видання «Адаптивне управління: теорія і практика.

Серія «Педагогіка»

Випуск 11(21), 2021

$+\mathrm{v} 14 * \mathrm{k} 14)$

14.Невідпрацьованість критеріїв оцінювання результатів (проміжних та/або кінцевих)

$14=0,25$

$\mathrm{K} 14=$

\begin{tabular}{|c|c|c|c|c|}
\hline & & & 206 & 8 \\
\hline 4. Командоутворення & $\mathrm{m} 4=$ & 15. Невдалий вибір лідера проєкту & $\mathrm{v} 15=0,2$ & $\mathrm{~K} 15=$ \\
\hline$\Phi 4=\mathrm{m} 4\left(\mathrm{v} 15^{*} \mathrm{k} 15+\right.$ & & 16. Замикання надто багатьох питань на лідерові проєкту & v16=0,1 & $\mathrm{K} 16=$ \\
\hline +v16*k16+v17*k17+ & & 17. Слабка комунікація членів команди & $v 17=0,16$ & $\mathrm{~K} 17=$ \\
\hline$+\mathrm{v} 20 * \mathrm{k} 20+\mathrm{v} 21 * \mathrm{k} 21+$ & & 18. Недостатній фаховий рівень членів команди & $\mathrm{v} 18=0,2$ & $\mathrm{~K} 18=$ \\
\hline$+\mathrm{v} 22 * \mathrm{k} 22+\mathrm{v} 23 * \mathrm{k} 23)$ & & 19. Недостатня мотивація членів команди & $\mathrm{v} 19=0,06$ & $\mathrm{~K} 19=$ \\
\hline & & 20. Протидія проєкту в колективі & $\mathrm{v} 20=0,05$ & $\mathrm{~K} 20=$ \\
\hline & & 21. Невиправдана заміна виконавців & $\mathrm{v} 21=0,05$ & $\mathrm{~K} 21=$ \\
\hline & & 22. Недостатньо повноважень у членів команди & $\mathrm{v} 22=0,07$ & $\mathrm{~K} 22=$ \\
\hline & & $\begin{array}{l}\text { 23. Нераціональний розподіл обов'язків між членами } \\
\text { команди(краунтфандінг, фандрайзинг) }\end{array}$ & $\mathrm{v} 23=0,11$ & $\mathrm{~K} 23=$ \\
\hline 5. Тайм-менеджмент & $\mathrm{m} 5=$ & 24. Невдалий графік розроблення проєкту & $\mathrm{v} 24=0,2$ & K24= \\
\hline$\Phi 5=\mathrm{m} 5(\mathrm{v} 24 * \mathrm{k} 24+$ & & 25. Невдалий графік впровадження проєкту & $\mathrm{v} 25=0,2$ & $\mathrm{~K} 25=$ \\
\hline $\begin{array}{l}+\mathrm{v} 25 * \mathrm{k} 25+\mathrm{v} 26 * \mathrm{k} 26+ \\
+\mathrm{v} 27 * \mathrm{k} 27)\end{array}$ & & 26. Втрата актуальності проєкту & $\mathrm{v} 26=0,5$ & $\mathrm{~K} 26=$ \\
\hline & & 27. «Розповзання» масштабу проэкту & $\mathrm{v} 27=0,1$ & $\mathrm{~K} 27=$ \\
\hline $\begin{array}{l}\text { 6. Ресурсний } \\
\text { менеджмент }\end{array}$ & $\mathrm{m} 6=$ & 28. Помилковий розрахунок ресурсів проєкту & $\mathrm{v} 28=0,33$ & $\mathrm{~K} 28=$ \\
\hline$\Phi 6=\mathrm{m} 6(\mathrm{v} 28 * \mathrm{k} 28+$ & & 29. Помилки у розрахунку бюджету проєкту & $\mathrm{v} 2 \overline{9}=0, \overline{3}$ & $\mathrm{~K} 29=$ \\
\hline$+\mathrm{v} 29 * \mathrm{k} 29+\mathrm{v} 30 * \mathrm{k} 30)$ & & 30. Невиправдані витрати & $\mathrm{v} 30=0, \overline{3}$ & $\mathrm{~K} 30=$ \\
\hline 7. Управління & $\mathrm{m} 7=$ & 31. Недооцінка ризиків & $\mathrm{v} 31=0,3$ & $\mathrm{~K} 31=$ \\
\hline
\end{tabular}

(C) Українська інженерно-педагогічна академія

(C) ГО «Школа адаптивного управління соціально-педагогічними системами»

(C) Шкура Г. 
Електронне наукове фахове видання «Адаптивне управління: теорія і практика.

Серія «Педагогіка»

Випуск 11(21), 2021

\begin{tabular}{|c|c|c|c|c|}
\hline ризиками & \multirow[t]{3}{*}{0,05} & & & \\
\hline \multirow{2}{*}{$\begin{array}{l}\Phi 7=\mathrm{m} 7(\mathrm{v} 31 * \mathrm{k} 31+ \\
+\mathrm{v} 32 * \mathrm{k} 32+\mathrm{v} 33 * \mathrm{k} 33)\end{array}$} & & 32. Недостатність досвіду щодо подолання ризиків & $\mathrm{v} 32=0,2$ & $\mathrm{~K} 32=$ \\
\hline & & 33. Невдале управління ризиками & $\mathrm{v} 33=0,5$ & $\mathrm{~K} 3 \overline{3}=$ \\
\hline 8. Зовнішні впливи & \multirow{3}{*}{$\begin{array}{c}\mathrm{m} 8= \\
0,04\end{array}$} & 34. Неврахування соціальної нестабільності & $\mathrm{v} 34=0,18$ & $\mathrm{~K} 34=$ \\
\hline \multirow{2}{*}{$\begin{array}{l}\Phi 8=\mathrm{m} 7(\mathrm{v} 34 * \mathrm{k} 34+ \\
+\mathrm{v} 35 * \mathrm{k} 35+\mathrm{v} 36 * \mathrm{k} 36)\end{array}$} & & 35. Завеликий вплив соціальної нестабільності & $\mathrm{v} 35=0,12$ & $\mathrm{~K} 35=$ \\
\hline & & 36. Втрата зацікавленості стейкхолдерів & $\mathrm{v} 36=0,7$ & $\mathrm{~K} 36=$ \\
\hline
\end{tabular}

\section{Критерії оцінювання:}

4 бали - утруднення відчуваються постійно;

3 бали - утруднення відчуваються часто;

2 бали - утруднення відчуваються час від часу

1 бал - утруднення відчуваються часто;

0 балів - утруднення практично не відчуваються.

(C) Українська інженерно-педагогічна академія

(c) ГО «Школа адаптивного управління соціально-педагогічними системами»

(C) ШкураГ. 